\title{
Щодо можливості застосування кластерного підходу під час розроблення та виробництва озброєння та військової техніки в Україні
}

\section{Валерій Борохвостов * А; Володимир Комаров ${ }^{\text {; }}$ Леся Скуріневська ${ }^{\text {; }}$} Анастасія Шевченко ${ }^{D}$

А Центральний науково-дослідний інститут озброєння та військової техніки Збройних Сил України, проспект Повітрофлотський, 28, м. Київ, 03049, Україна в Військова частина А1906, м.Київ-04050, Україна

с Національний університет оборони України імені Івана Черняховського, пр-кт Повітрофлотський, 28, м Київ, 03049, Україна D Національний інститут стратегічних досліджень, вул. Пирогова, 7а, м. Київ, 01030, Україна

Received: October 03, 2020 | Revised: October 26, 2020 | Accepted: October 31, 2020

DOI: $10.33445 /$ sds.2020.10.5.8

\begin{abstract}
Анотація
У статті висвітлено сучасний стан та проблеми створення та організації серійного виробництва нових зразків озброєння та військової техніки для Збройних Сил України. На основі аналізу виробничо-економічних процесів та форм організації виробництва в оборонній промисловості окремих країн світу розкрито сутність, переваги й шляхи реалізації кластерного підходу, що може бути застосований під час розроблення та серійного виробництва нових зразків озброєння та військової техніки в Україні. Запропоновано загальну структуру такого кластеру, деталізовано порядок його створення та принципи функціонування, а також можливий вплив на підвищення ефективності реалізації програм технічного оснащення Збройних Сил України.
\end{abstract}

Ключові слова: військово-технічна політика, державне оборонне замовлення, керуюча кластерна організація, кластер, озброєння та військова техніка, розроблення озброєння та військової техніки, серійне виробництво озброєння та військової техніки.

\section{Постановка проблеми}

Суттєві зміни у геостратегічному, воєннополітичному, соціально-економічному та демографічному стані України, що відбулися за роки незалежності та прискорилися протягом останніх років, викликають необхідність розроблення нових підходів до питань забезпечення її національної безпеки у воєнній сфері, у тому числі щодо визначення найбільш раціональних з воєнної та економічної точок зору шляхів забезпечення Збройних Сил (ЗС) України новітніми та модернізованими зразками озброєння та військової техніки (ОВТ) у стислі терміни, а також вирішення багатьох інших питань воєнно-технічної політики (ВТП) України.

Складність та масштабність цих проблем обумовлює необхідність ретельного опрацювання та узгодження змісту зазначених питань, термінів реалізації та потрібних для цього ресурсів. Саме тому фахівцями Міністерства оборони (МО) України, ЗС та Генерального штабу (ГШ) 3 С України під час обґрунтування завдань і заходів планових та програмних документів оборонного планування щодо розвитку ОВТ та оснащення ними військових формувань сил оборони України проводиться комплекс наукових досліджень, що у довгостроковій та середньостроковій перспективах узагальнено спрямовані на визначення (наукове обґрунтування):

- військових загроз національній безпеці України;

- переліку спроможностей, що необхідно

\footnotetext{
* Corresponding author: провідний науковий співробітник, к.т.н., доцент, e-mail: bvk51@ukr.net, ORCID: 0000-0001-6341-9042
} 
досягти для забезпечення визначеного рівня військової безпеки;

- тенденцій розвитку і технологій створення ОВТ, результатів фундаментальних та прикладних досліджень в Україні та світі;

- потреб сил оборони у кількісно-якісному складі (КЯС) системи озброєння сил оборони (кількість та номенклатура за типами ОВТ);

- оперативно-тактичних (ОТВ) та тактикотехнічних вимог (ТТВ) до нових та модернізованих зразків (комплексів, систем) OBT із розробленням тактико-технічного завдання (ТТЗ) на їх створення;

- можливостей підприємств обороннопромислового комплексу (ОПК) України щодо розроблення та серійного виробництва зразків ОВТ або їх складових частин;

- шляхів забезпечення військових формувань сил оборони ОВТ (замкнений цикл створення і виробництва в України, міжнародна кооперація, лізинг, офсет, закупівля за кордоном зразків або їх складових частин тощо).

Проведення таких досліджень має циклічний характер, а їх результатом $\epsilon$ формування основних напрямів розвитку ОВТ на довгострокову перспективу, Державної цільової оборонної програми розвитку (ДЦОПР) ОВТ на середньострокову перспективу та Державного оборонного замовлення (ДОЗ) на три роки. У цьому процесі значний вплив на змістовне наповнення зазначених документів має фінансовий ресурс, який держава спроможна виділити на забезпечення сил оборони ОВТ. Його перманентна недостатність для переозброєння військових формувань на рівні потреби обумовлює визначення пріоритетного ряду типів ОВТ, що першочергово необхідно розвивати, розробляти та закуповувати за роками програмного періоду. За складний процес досягнення балансу між виділеними асигнуваннями та задоволенням потреб сил оборони в КяС ОВТ відповідають методологія оборонного планування та науковометодичні апарати воєнно-економічного аналізу (BEA), обґрунтування і науково- технічного супроводження (НTC) середньострокових програм озброєння, що застосовуються та постійно вдосконалюються науково-дослідними установами (НДУ) МО України.

Існуюча в Україні система оборонного планування розвитку ОВТ, основу якої складають затверджені на державному рівні стратегічні та концептуальні документи, дозволяє комплексно обґрунтовувати виділення фінансового ресурсу на розроблення та закупівлю ОВТ для потреб сил оборони. Але на даний час більша частина порівняно невеликих асигнувань спрямовується на забезпечення першочергових потреб в основних «класичних» типах ОВТ, що, в першу чергу, застосовуються у збройному конфлікті на сході України.

Також необхідно зазначити, що закладене Урядом України в ДЦОПР ОВТ фінансування $є$ обмеженим вже на етапі планування. Так, наприклад, при розробленні чинної на цей час ДЦОПР ОВТ на період до 2022 р. попередньо обрахована потреба у фінансуванні заходів 3 розроблення та закупівлі ОВТ для ЗС України на 2016-2020 р. склала понад 800 млрд. грн у цінах 2015 року. у той же час, держава обмежила обсяг фінансування цих заходів до 107,5 млрд. грн. У подальшому при внесенні змін до діючої програми обсяг фінансування цих заходів ще зменшився: спочатку до 80 млрд грн, згодом - до 70 млрд грн.

Іншими чинниками, що не знаходяться у компетенції МО України, але негативно впливають на ефективність оснащення 3 С України ОВТ є: неспроможність вітчизняного ОПК задовольнити усі потреби ЗС України. За оцінками експертного середовища, український ОПК на цей час спроможний виробляти за замкненим циклом тільки близько 5-8 \% загальної номенклатури ОВТ для потреб ЗС України; неможливість виробника досягти визначених у ТТЗ характеристик зразка ОВТ при проведенні ДКР в установлені терміни; збільшення заявленої вартості продукції в процесі їі виробництва з причин, що не залежать від 


\begin{tabular}{lcr}
\hline виробника; & несвоєчасне & постачання \\
продукції & оборонного & призначення \\
&
\end{tabular}
підприємствами-виробниками до ЗС України; банкрутство підприємства-виробника продукції оборонного призначення, з яким МО України уклало державні контракти.

Розглядаючи оборонно-промислову складову ВТП України, можна виділити такі її основні проблеми на сучасному етапі: структурна деформація та незбалансованість ОПк; незадовільне фінансово-економічне становище ОПК; відсутність інвестиційних ресурсів; залежність підприємств від імпортних поставок; низька економічна ефективність використання в умовах ринкової економіки наявного потенціалу комплексу; недостатній рівень стратегічного менеджменту на всіх ланках управління ОПК та невідповідність схеми управління ОПК взагалі новим економічним умовам; старіння основних виробничих фондів (спрацювання виробничої бази складає від 60 \% до $80 \%$, частка обладнання віком понад 10 років сягає 80-96 \%); низька рентабельність оборонних підприємств; суттєве зменшення чисельності та якості кадрового потенціалу ОПк; невідповідність, як за номенклатурою так і обсягами випуску, потужностей вітчизняного ОПК потребам оборонного замовлення; обмеженість технологічних, наукових та виробничих спроможностей промисловості України; недостатнє залучення до створення та виробництва ОВТ підприємствами вітчизняного ОПК здобутків вітчизняної прикладної та фундаментальної науки; недостатнє використання підприємствами вітчизняного ОПК інвестиційних можливостей недержавного сектору економіки та військово-технічного співробітництва.

Крім того, в Україні загальна кількість дослідників за роки незалежності зменшилася майже у 5 разів, і якщо в 1991 р. їх було понад 4 тис. осіб на 1 млн. населення, то сьогодні - 1254 особи, що у 2,6 рази менше, ніж в середньому в країнах ЄС. При цьому скорочення кадрового потенціалу науки в України триває, посилюється відплив вітчизняних науковців, насамперед, молодих учених, за кордон. Вітчизняна наука перетворюється на донора для нарощування наукового потенціалу інших країн. Як наслідок, наукоємність ВВП в Україні скоротилася у кілька разів і становила у 2017 р. 0,45 \% ВВП - мінімальне значення цього показника за всю історію незалежності України (наприклад, у 1991 р. наукоємність ВВП становила 2,5\%), а тенденції розвитку науки взагалі не відповідають світовому рівню.

\section{Аналіз останніх досліджень та публікацій}

Аналіз свідчить, що для вирішення зазначених проблем 3 точки зору законодавчого забезпечення в Україні зроблено чимало, проте існує багато невирішених питань, зокрема, у сфері організації та забезпечення розроблення й серійного виробництва нових зразків ОВТ.

У низці законів України, постанов та розпоряджень Кабінету міністрів (КМ) України, зокрема [1-6], розкриті основи формування, планування та забезпечення державної ВТП України, формування та організації виконання ДОЗ [1-4], розроблення та постановки на серійне виробництво зразків ОВТ [2-4, 5], порядок укладення договорів на виконання ДОЗ та встановлення цін на продукцію і послуги оборонного призначення [2-4, 6] тощо. У той же час, у ході практичної реалізації окремих зазначених у даних законодавчо-нормативних актів положень виникають проблеми, що призводять до зниження воєнно-економічної ефективності функціонування системи забезпечення ЗС України потрібними зразками ОВТ. Саме це визначає актуальність питань, що розглядаються у даній статті, метою якої $€$ розроблення пропозицій щодо впровадження під час виконання дОЗ із забезпечення ЗС України новітніми зразками ОВТ нових прогресивних інструментів, зокрема, моделі кластерної організації розроблення та серійного виробництва. 


\section{Постановка завдання}

Аналізуючи існуючу в Україні систему, слід зазначити, що на початку розроблення складного зразка ОВТ здійснюється його попередня декомпозиція на основні окремі, відносно самостійні складові частини, що забезпечують виконання ним основних функцій, розроблення й серійне виробництво яких, за наявним ретроспективним досвідом, здійснюються різними установами та підприємствами. Оцінювати їхні наукові та виробничі можливості слід на етапі розроблення ТТВ до кожної складової частини потрібного зразка ОВТ та наявності у цих установах і підприємствах або готових розробок, що задовольнятимуть висунутим вимогам, або їх досвіду та спроможності й готовності такі складові частини створювати й виробляти. При цьому існує широке поле для виконання робіт - від застосування вже готової складової частини (або її окремої частки) у новому потрібному зразку ОВТ без жодної ії̈ переробки, або відповідна їі переробка з метою пристосування для роботи у складі створюваного зразка ОВТ. Якщо у даних установах і підприємствах немає готових для використання на потрібному зразку ОВТ складових частин, але $\epsilon$ досвід й виробничі можливості щодо їх створення і серійного виробництва, то їм може буде доручене виконання даного завдання, що має буде підтверджено відповідними техніко-економічними розрахунками.

\section{Виклад основного матеріалу}

Враховуючи вищевикладене, авторами статті були проаналізовані типові ситуації, що виникають у тій чи іншій установі (організації) під час попередньої оцінки можливостей своєчасного та якісного виконання робіт 3 розроблення основних складових частин створюваного зразка ОВТ, основні з яких наведено у табл. 1 (у порядку їх ускладнення).

Таблиця 1 - Типові ситуації щодо наукового, технологічного та виробничого забезпечення під час виконання ДКР із створення складових частин для новітнього зразка ОВТ

\begin{tabular}{|c|c|}
\hline $\begin{array}{l}\text { № } \\
\text { ситуа- } \\
\text { цій }\end{array}$ & Головний зміст ситуацій \\
\hline 1. & $\begin{array}{l}\text { Потрібна складова частина розроблена й серійно виробляється для встановлення на інші } \\
\text { зразки ОВТ. Може бути застосована для створюваного зразка ОВТ без доопрацювання }\end{array}$ \\
\hline 2. & $\begin{array}{l}\text { Потрібна складова частина розроблена й серійно виробляється для встановлення на інші } \\
\text { зразки ОВТ. Може бути застосована для створюваного зразка ОВТ із незначним } \\
\text { доопрацюванням. Науковий, технологічний та виробничий потенціали для цього в установах } \\
\text { та на підприємствах України наявні }\end{array}$ \\
\hline 3. & $\begin{array}{l}\text { Потрібна складова частина розроблена й серійно виробляється для встановлення на інші } \\
\text { зразки ОВТ. Може бути застосована для створюваного зразка ОВТ із значним } \\
\text { доопрацюванням. Науковий, технологічний та виробничий потенціали для цього в установах } \\
\text { та на підприємствах України наявні }\end{array}$ \\
\hline 4. & $\begin{array}{l}\text { Потрібна складова частина розроблена й серійно виробляється для встановлення на інші } \\
\text { зразки ОВТ. Може бути застосована для створюваного зразка ОВТ із значним } \\
\text { доопрацюванням. Науковий, технологічний або виробничий потенціали для цього в установах } \\
\text { та на підприємствах України частково відсутні. Можливе залучення іноземних партнерів для } \\
\text { розробки окремих вузлів і деталей }\end{array}$ \\
\hline 5. & $\begin{array}{l}\text { В Україні } € \text { досвід створення потрібних складових частин, але їх серійне виробництво } \\
\text { припинене. Розробку та серійне виробництво можливо відновити. Зразки ОВТ з аналогами } \\
\text { потрібних складових частин перебувають на оснащенні ЗС України }\end{array}$ \\
\hline 6. & $\begin{array}{l}\text { В Україні є досвід, науковий, технологічний та виробничий потенціали зі створення } \\
\text { складових частин, аналогічних потрібним для нового зразка ОВТ. Серійне виробництво }\end{array}$ \\
\hline
\end{tabular}




\begin{tabular}{|c|c|}
\hline $\begin{array}{c}\text { № } \\
\text { ситуа- } \\
\text { цій }\end{array}$ & Головний зміст ситуацій \\
\hline & $\begin{array}{l}\text { аналогів складових частин для потрібного зразка ОВТ зараз продовжується. Зразки ОВТ з } \\
\text { аналогами потрібних складових частин перебувають на оснащенні ЗС України }\end{array}$ \\
\hline 7. & $\begin{array}{l}\text { В Україні } € \text { досвід, науковий, технологічний та виробничий потенціали зі створення } \\
\text { складових частин, аналогічних потрібним для нового зразка ОВТ. Серійне виробництво } \\
\text { аналогів складових частин для потрібного зразка ОВТ припинене, але його можливо } \\
\text { відновити. Зразки ОВТ з аналогами потрібних складових частин перебувають на оснащенні ЗС } \\
\text { України }\end{array}$ \\
\hline 8. & $\begin{array}{l}\text { В Україні був, однак впродовж кількох років вже не використовувався досвід, науковий, } \\
\text { технологічний та виробничий потенціали зі створення та серійного виробництва складових } \\
\text { частин, аналогічних потрібним для нового зразка ОВТ. Серійне виробництво аналогів } \\
\text { складових частин для потрібного зразка ОВТ припинене. Для розроблення й серійного } \\
\text { виробництва окремих вузлів та деталей для потрібної складової частини можливе залучення } \\
\text { іноземних партнерів. Зразки ОВТ з аналогами потрібних складових частин перебувають на } \\
\text { оснащенні ЗС України }\end{array}$ \\
\hline 9. & $\begin{array}{l}\text { В Україні був, однак впродовж кількох років вже не використовувався досвід, науковий, } \\
\text { технологічний та виробничий потенціали зі створення та серійного виробництва складових } \\
\text { частин, аналогічних потрібним для нового зразка ОВТ. Серійне виробництво аналогів } \\
\text { складових частин для потрібного зразка ОВТ припинене. Для розроблення й серійного } \\
\text { виробництва окремих вузлів та деталей для потрібної складової частини можливе залучення } \\
\text { іноземних партнерів. Зразки ОВТ з аналогами потрібнихскладових частин вже не перебувають } \\
\text { на оснащенні ЗС України }\end{array}$ \\
\hline 10. & $\begin{array}{l}\text { В Україні немає досвіду зі створення та серійного виробництва аналогів складових частин, } \\
\text { необхідних для потрібного зразка ОВТ, однак є науковий, технологічний та виробничий } \\
\text { потенціали, що можуть бути використані для цього. За кордоном є досвід створення та } \\
\text { серійного виробництва аналогів складових частин для потрібного зразка ОВТ. Можливе } \\
\text { залучення іноземних партнерів для розроблення й серійного виробництва окремих вузлів та } \\
\text { деталей для потрібної складової частини. Аналоги зразка ОВТ з потрібними складовими } \\
\text { частинами перебувають на оснащенні ЗС України (куплені або поставлені із-за кордону) }\end{array}$ \\
\hline 11. & $\begin{array}{l}\text { В Україні немає досвіду, технологічного та виробничого потенціалів зі створення аналогів } \\
\text { складових частин для потрібного зразка ОВТ, однак } є \text { науковий потенціал, що може бути } \\
\text { використаний для цього. За кордоном } є \text { досвід створення та серійного виробництва аналогів } \\
\text { складових частин для потрібного зразка ОВТ. Можливе залучення іноземних партнерів для } \\
\text { розроблення й серійного виробництва окремих вузлів та деталей для потрібної складової } \\
\text { частини. Аналогів зразка ОВТ з потрібними складовими частинами на оснащенні ЗС України } \\
\text { немає }\end{array}$ \\
\hline 12. & $\begin{array}{l}\text { Досвіду, наукового технологічного та виробничого потенціалів зі створення потрібної } \\
\text { складової частини для створюваного зразка ОВТ в Україні немає. Передумови для їх набупя } \\
\text { відсутні. За кордоном є досвід створення та серійне виробництво аналогів складових частин } \\
\text { для потрібного зразка ОВТ. Можливе залучення іноземних партнерів для розроблення й } \\
\text { серійного виробництва даної потрібної складової частини, або для закупівлі вже наявної } \\
\text { складової частини, з наступною її незначною доробкою для встановлення на створюваний } \\
\text { зразок ОВТ }\end{array}$ \\
\hline 13. & $\begin{array}{l}\text { Досвіду та наукового потенціалу зі створення потрібної складової частини для створюваного } \\
\text { зразка ОВТ в Україні і за кордоном немає. }\end{array}$ \\
\hline
\end{tabular}

3 даних ситуацій для кожної створюваної складової частини ії розробниками та виробниками дослідних зразків (співвиконавцями ДКР з розроблення зразка
ОВТ) обирається одна, що найбільше відповідає сучасному стану справ у тому або іншому випадку. Виходячи з цього, оцінюється можлива вартість й строки виконання робіт із 
створення кожної складової частини даного та наступного серійного виробництва зразка ОВТ. потрібного нового зразка ОВТ послідовно

Виходячи з наведеного, під час розроблення виконуються такі операції (рис. 1) (укрупнено).

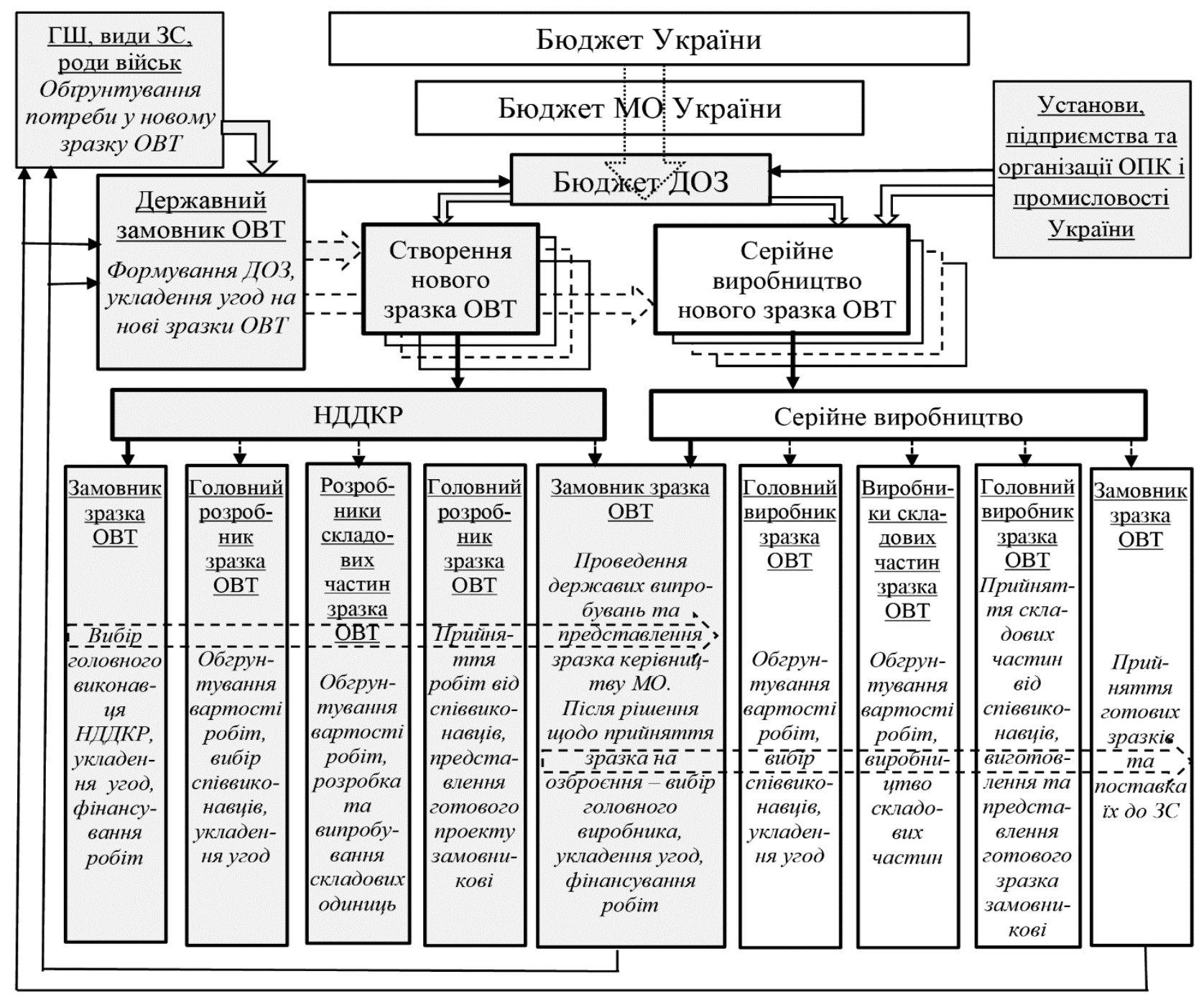

Малюнок 1 - Загальна схема процесу розроблення та серійного виробництва нового зразка ОВТ

1. Розроблення та обґрунтування ГШ ЗС України ОСВ та ОТВ до потрібного зразка ОВТ.

2. Розроблення державним замовником ТТВ до потрібного зразка ОВТ з подальшою деталізацією його ТTX.

3. Розроблення державним замовником ТT3 на проведення ДКР із створення потрібного зразка ОВТ, погодження його з ймовірним головним виконавцем роботи та укладення 3 ним контракту на виконання ДКР у цілому щодо зразка ОВТ.

4. Відбір головним виконавцем ДКР співвиконавців ДКР із розроблення складових частин створюваного зразка ОВТ, розроблення ТТЗ на кожну складову частину та укладення відповідних контрактів із кожною окремою установою (організацією).

5. Організація та координація головним виконавцем ДКР роботи із розроблення зразка ОВТ у цілому, контроль виконання робіт із розроблення складових частин співвиконавцями, звіти в установлені терміни про хід виконання робіт державному замовникові.

6. Проведення після завершення ДКР державних випробувань створеного зразка ОВТ та, у разі позитивного результату, прийняття рішення щодо прийняття його на озброєння ЗС України.

7. Організація серійного виробництва створеного зразка ОВТ. Відбір головного 
виробника зразка ОВТ та укладення контракту між ним та державним замовником.

8. Відбір головним виробником зразка ОВТ співвиконавців із серійного виробництва складових частин створеного зразка ОВТ та укладення ним відповідних контрактів із кожною окремою установою (організацією).

9. Організація головним виробником зразка ОВТ серійного виробництва зразка ОВТ у цілому, використовуючи для цього складові частини, виготовлені їх співвиконавцями, та здача готових зразків ОВТ державному замовникові.

Аналіз наведених операцій та практики їх виконання під час створення та серійного виробництва різних складних зразків ОВТ у фінансово-економічних та виробничотехнологічних умовах України свідчить, що найбільш відповідальним та непередбачуваним з точки зору витрат часу й фінансових ресурсів $\epsilon$ процес виконання ДКР 3 розроблення складових частин створюваного зразка ОВТ (рис. 2), якщо він відбувається у кількох установах (організаціях) за різними наведеними у табл. 1 умовами. У ході ДКР під час опрацювання нових конструктивних й технологічних рішень виникає багато несподіваних обставин і явищ, що часто призводять до зриву встановлених під час укладення контрактів термінів виконання окремих робіт, зростанню їх вартості тощо, а в окремих випадках - навіть до припинення подальших робіт з обраного проекту.

На нашу думку, це обумовлюється кількома причинами. 1) кожен співвиконавець під час розроблення дорученої йому складової частини зразка ОВТ спирається лише на власний науково-технологічний та виробничотехнологічний потенціал; 2) кожен співвиконавець на виконання робіт витрачає кошти в межах виділених для нього асигнувань; 3) наукові, виробничі та технологічні зв'язки між співвиконавцями з розробки окремих складових частин зразка ОВТ практично відсутні. у той же час, динамізація економічних процесів, посилення глобалізаційних тенденцій та зростання ролі інституціональних чинників економічного розвитку, у тому числі в оборонній промисловості наприкінці XX початку XXI ст. стимулювали поширення процесів так званої квазіінтеграції компаній об'єднання економічних суб'єктів, що передбачає розвиток стійких довгострокових зв'язків між ними та делегування контролю над управлінням спільною діяльністю за відсутності юридично оформленого трансферу прав власності.

На нашу думку, одним зі шляхів виходу з несприятливого стану, що склався останніми роками в оборонній промисловості України, $€$ застосування під час розроблення зразка ОВТ та його подальшого серійного виробництва однієї з форм квазіінтеграції - так званої кластерної організації виробництва, що останнім часом знаходить все більше застосування в економічних відносинах та організації виробництва продукції у різних галузях промисловості провідних країн світу, у тому числі - В оборонній промисловості.

Зародження кластерної теорії як напряму економічної думки стало відповіддю на глобальні зміни світової кон'юнктури, пов'язані з загостренням конкуренції на світових ринках, що спонукало країни до пошуку нових джерел економічного зростання та конкурентних переваг.

Автором сучасної кластерної теорії вважається М. Портер, який розглядає кластери з позицій теорії конкуренції та визначає їх як сконцентровані за географрічною ознакою групи взаємопов'язаних компаній, спеціалізованих постачальників, постачальників послуг, фірм у споріднених галузях, а також пов'язаних з їхньою діяльністю організацій (наприклад, університетів, агентств зі стандартизації, торговельних об'єднань) у визначеній сфері, які конкурують, але при цьому здійснюють спільну діяльність [7]. 


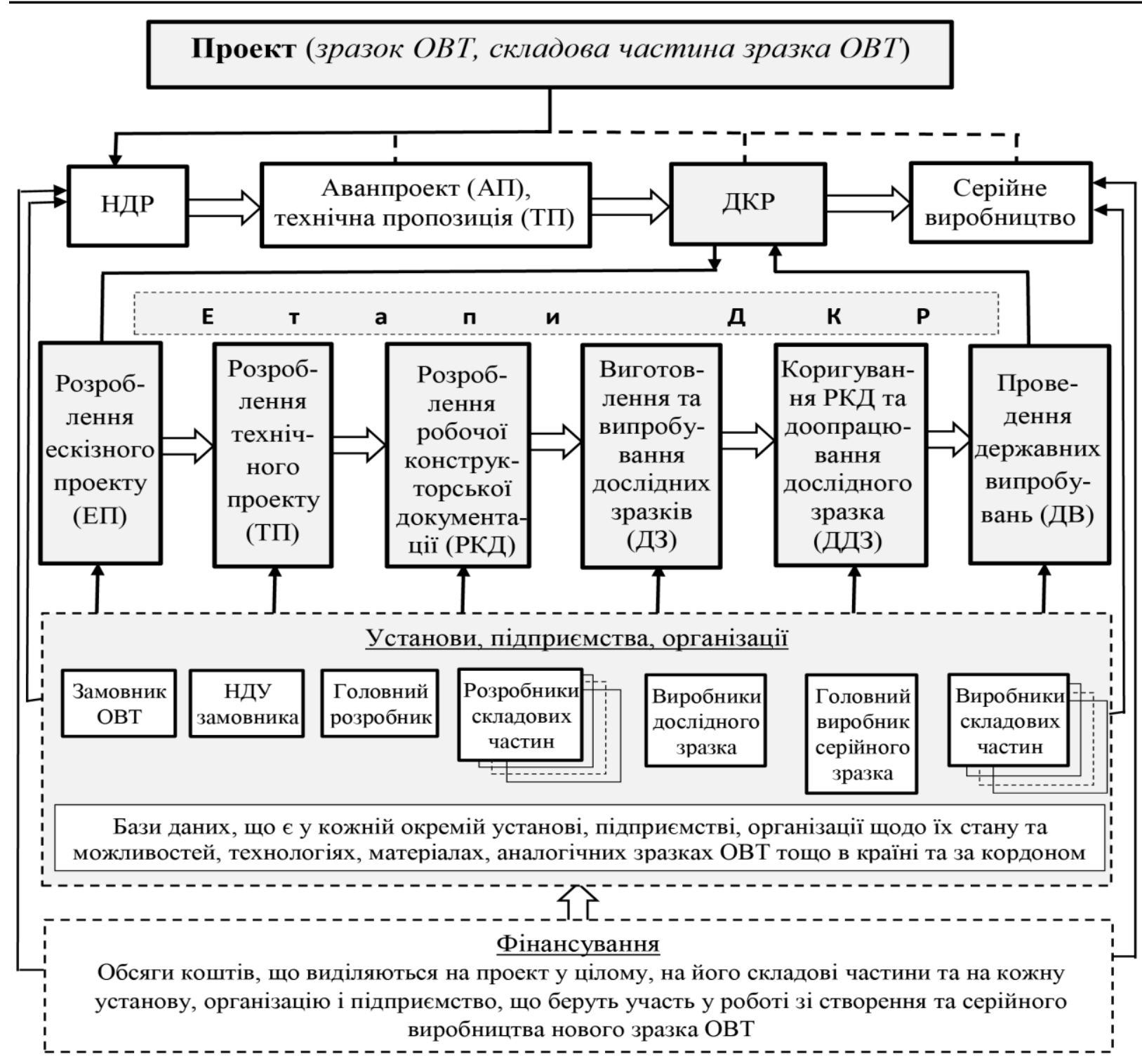

Малюнок 2 - Загальна схема проведення ДКР із розроблення зразка ОВТ (складової частини зразка ОВТ)

Дослідники теорії кластеризації до переваг кластерів відносять: відсутність жорсткої ієрархії всередині кластера, балансування інтересів різних учасників ринку при збереженні ними незалежності у прийнятті рішень; збереження конкурентного середовища всередині кластера, що стимулює учасників кластера до постійного саморозвитку та перешкоджає утворенню застиглих ригідних структур; зростання ефрективності роботи компаній завдяки більш швидкому доступу до ресурсів, знань, інноваційних технологій та постачальників, а також завдяки зменшенню трансакційних витрат; створення унікальних умов для розвитку малого бізнесу (у тому числі інноваційного) завдяки високому попиту на вузькоспеціалізовані «нішеві» виробництва та налагодженість зв'язків з партнерами всередині кластеру; заміщення коопераційних процесів коеволючійними, що передбачає узгоджене формування планів, вироблення спільного бачення та колективних цінностей у процесі адаптації учасників до мінливого соціальноекономічного середовища, підвищуючи передбачуваність ринкового середовища завдяки формуванню вірогідних очікувань щодо планів інших компаній; активізація інноваційної діяльності компаній - завдяки т. з. «ефекту переливу» (spill-over effect) та більш тісному контакту зі споживачами та іншими компаніями 
виникають можливості створення та поширення нових ідей та технологій серед учасників кластеру та за його межі; інтерактивний характер інноваційної діяльності, що значно розширює коло учасників інноваційного процесу, дозволяючи всім компаніям та організаціям кластера брати участь у створенні, поширенні та використанні інновацій, прискорює створення нових продуктів та послуг; створення замкненого виробничого циклу у межах кластера завдяки виявленню та створенню відсутніх у виробництві ланок тощо.

Багатьма країнами світу вже накопичено значний успішний досвід розвитку кластерів в оборонній індустрії, що дозволяє отримати найбільш ефективну модель співробітництва між державою, бізнесом, наукою та кінцевими споживачами з урахуванням специфіки сектору безпеки і оборони. Узагальнення міжнародного досвіду у цій сфері дозволяє виділити характерні риси оборонних кластерів, що полягають у наступному:

інноваційна спрямованість виробництва. За оцінками експертів реалізація проектів 3 виробництва складної інноваційної військової техніки у рамках кластеру дозволяє скоротити трансакційні витрати щонайменше на 10-15 \% [8]. Так, у ЄС переважна частина кластерів оборонної індустрії спеціалізується на розробленні та виробництві інноваційної продукції та технологій - аерокосмічної техніки, нових матеріалів, нанота фотонних технологій тощо [9]. Значну роль у посиленні інноваційної спрямованості та нарощуванні конкурентоспроможності оборонних кластерів відіграє активне залучення до них не лише воєнних, а й цивільних компаній, зокрема, IT-сектору та високотехнологічного машинобудування, що також дозволяє реалізовувати проекти з виробництва продукції подвійного призначення. Наприклад, хорватським кластером конкурентоспроможності в оборонній індустрії завдяки розвитку міжсекторального співробітництва налагоджується виробництво безпілотних комплексів, цифрових та комунікаційних технологій, засобів протидії біологічним атакам [10]. Важливими механізмами інноваційного розвитку виступають співробітництво оборонних компаній з сектором досліджень та розробок (університетами,

науково-дослідними

інститутами), участь у регіональних та міжнародних проектах та програмах;

провідна роль держави у створенні та розвитку оборонних кластерів. Специфіка оборонної індустрії полягає у високій частці компаній державної форми власності, обмеженому доступі до воєнних технологій та розробок, високій пріоритезації сектору безпеки і оборони з позицій забезпечення національної безпеки. Це обумовлює значну зацікавленість у розвитку оборонних кластерів з боку органів державної влади, що часто виступають ініціаторами їх створення (т. зв. підхід “згоривниз", тоді як в економіці загалом переважає підхід "знизу-вгору", коли ініціаторами створення кластерів виступає приватний сектор). Зважаючи на складність та високу вартість проектів в оборонній сфері, їх реалізація напряму залежить від державної підтримки. Намагаючись максимально локалізувати виробництва оборонного сектору всередині країни, уряди іноземних держав активно впроваджують фінансові інструменти підтримки оборонних кластерів - податкові пільги, зниження ренти, доступ до дешевих кредитів та фондів тощо [11]. Крім того, значна увага приділяється розвитку необхідної для розвитку кластерів інфраструктури;

наявність потужного кластерного менеджменту у вигляді спеціально створеної для кожного кластера керуючої організації, що розробляє та впроваджує стратегію його розвитку, забезпечує та розподіляє організаційну, фінансову, сервісну та інші види підтримки між членами кластера під час реалізації проектів. Зокрема, найважливішими функціями керуючої організації є налагодження та підтримка співробітництва членів кластера між собою та 3 урядовими установами і організаціями, приватними компаніями, науковим сектором та клієнтами; залучення до кластера нових членів; сприяння отриманню сертифікатів для нової продукції; забезпечення участі членів кластера у національних та міжнародних виставках, конференціях, семінарах, професійних тренінгах тощо;

активне залучення до участі в оборонних кластерах малих та середніх підприємств 
(МСП), що дозволяє диверсифікувати продукцію кластера завдяки нішевості та високому рівню спеціалізації МСП, їх гнучкості та здатності швидко адаптувати технічні характеристики продукції та послуги до вимог великих підприємств-замовників. Так, в оборонній індустрії $Є С$ нараховується більше 2,5 тис. МСП, що відіграють ключову роль у виробництві оборонної продукції [12]. На думку експертів найефективнішою моделлю організації оборонного кластера $€$ співробітництво декількох великих компаній, що отримують оборонне замовлення, зі спеціалізованими МСП, що працюють на умовах субконтрактингу. У деяких країнах поширеними є моделі оборонних кластерів, що складаються лише з МСП. Наприклад, перші три оборонні кластери у Туреччині, метою створення яких була підтримка малого інноваційного бізнесу та налагодження його співробітництва з великими оборонними підприємствами та між собою [13].

Слід визнати значне відставання України у сфері кластеризації економіки, у т. ч. В оборонній сфері. Перші спроби впровадження кластерів в ОПК України було здійснено ДП „Укроборонпром” у презентованій ним у 2016 р. Стратегії реформування ОПК [14], де було передбачено створення на базі підприємств концерну п'яти оборонних кластерів авіаційного, бронетанкового, суднобудівного, високоточного озброєння, радіолокаційних систем та зв'язку. Головною метою діяльності цих кластерів було визначено будівництво ефективної мережі взаємодії між наукою, бізнесструктурами та виробничими підприємствами для максимально швидкого впровадження інновацій як військового, так і цивільного призначення, а також підвищення конкурентоспроможності вітчизняної продукції на світових ринках. У червні 2016 р. на базі ДП "Антонов" навіть було створено перший кластер - Українську авіабудівну корпорацію [15].

Завдання кластеризації ОПК знайшло відображення у Стратегії розвитку ОПК України на період до 2028 року [16], до напрямів реалізації якої віднесено, у тому числі, впровадження моделі вертикально інтегрованих структур за кластерами. Проте через відсутність необхідних інституційних реформ та затвердженої законодавчої бази для розвитку оборонних кластерів суттєвого прогресу за цими напрямами за минулі роки в Україні не відбулося.

Пропозиції щодо створення в Україні кластерів під час виконання

контрактів із розроблення та серійного виробництва ОВТ

Виходячи з наведеного аналізу, автори статті пропонують зосередити зусилля не на створенні великих галузевих кластерів, запропонованих у Стратегії реформування ОПК [14], а на створенні невеликих проектних кластерів, призначених для вирішення «вузьких» практичних завдань, зокрема - розроблення та супроводження серійного виробництва одного конкретного зразка ОВТ. Для кожного нового зразка ОВТ пропонується створювати окремий вузько спеціалізований кластер. При цьому члени такого кластеру (підприємства, установи, організації, окремі спеціалісти) можуть входити й до інших кластерів. Приблизна структура такого кластера, розроблена авторами статті, наведена на рис. 3.

Основними структурними одиницями кластеру мають бути:

1. Керуюча кластерна організація, що складається з трьох структур:

1.1) Ради директорів членів кластеру, що $€$ представницьким органом і відповідає за внутрішню та зовнішню політику кластера, здійснює стратегічне планування й забезпечує його діяльність.

1.2) Виконавчого комітету-робочого органу кластеру, що складається 3 науковців, конструкторів і технологів усіх членів кластеру, та відповідає за розроблення й імплементацію політики діяльності кластеру, його всебічний розвиток, оперативне вирішення поточних наукових, технологічних й виробничих питань тощо.

1.3) Сервісної мережі, до складу якої входять організації та підприємства, що не беруть безпосередньої участі у діяльності та проектах кластера, а лише забезпечують умови для ії здійснення на контрактній основі.

Керуюча кластерна організація виконує дві основні функції: надання послуг (створення базової інфраструктури для діяльності кластера, утримання офісу, ведення веб-сайту кластера, 
здійснення інформаційної розсилки, організація зустрічей учасників кластера, надання консультаційних послуг, здійснення ринкових досліджень тощо) та реалізація проектів за участю окремих учасників кластеру (розроблення нової продукції, створення робочих груп для вирішення поточних екстрених питань з наукового обґрунтування та практичного вирішення окремих проблем, що виникають у того чи іншого учасника кластеру).

\section{2. Члени кластеру:}

2.1) виконавці ДКР - організації, установи, підприємства всіх форм власності (ї окремі підрозділи), що беруть безпосередню участь у розробленні потрібного нового зразка ОВТ або його складових частин;

2.2) представники державного замовника потрібного нового зразка ОВТ (відповідні структури МО, ГШ ЗС України, їхні НДУ тощо);

2.3) представники інших міністерств та відомств України, які беруть участь у роботі кластеру та сприяють його безперебійній діяльності тощо;

2.4) підприємства ОПК та промисловості України всіх фоорм власності, які здійснюють серійне виробництво зразка ОВТ у цілому, його складових частин, необхідних матеріалів тощо;

2.5) інші установи, організації, підприємства, що виявили бажання приєднатися до роботи кластеру, у тому числі - 3 інших держав.

Процес створення та організації діяльності кластеру

1. Ініціатором створення кластеру має бути орган державної влади, що відповідає за державну ВТП - нещодавно створене Міністерство з питань стратегічних галузей промисловості України, у співпраці з МО України, що найбільше зацікавлене в максимально швидкому отриманні потрібного нового зразка ОВТ та ефективному використанні коштів державного бюджету, виділеного на воєнні потреби.

2. Пропозиції щодо створення можливого кластеру та складу його учасників мають обговорюватися під час опрацювання концепції потрібного нового зразка ОВТ та виконання аванпроекту 3 його розроблення. Фактичне створення кластеру має відбуватися при вирішенні питання щодо включення ДКР 3 розроблення потрібного нового зразка ОВТ до складу ДОЗ.

3. У першу чергу має бути створена керуюча кластерна організація, що повинна підготувати всі необхідні установчі документи для створення й функціонування кластеру. Вхід до складу кластеру для всіх установ, організацій та підприємств має бути добровільним, 3 зацікавленістю їх в найшвидшому отриманні позитивного кінцевого результату та прибутку, спрямованого на розвиток їх організацій та матеріальне заохочення.

4. Учасникам кластеру державою в установленому порядку мають надаватися податкові та інші пільги і преференції виходячи з того, що на початковому етапі розвитку кластеру вкрай важливо забезпечити організаційну та фінансову підтримку створення професійного кластерного менеджменту, адже учасники кластерів на початок їхньої діяльності не схильні платити внески для забезпечення роботи таких організацій через брак довіри та відсутність реальних результатів. Рівень державної підтримки кластеру має залежати від результатів його роботи.

5. Для ефективної роботи кластеру обов'язково мають бути створені:

- загальна (спільна) інфрормаційна база даних кластеру з доступом до неї, в установленому порядку, всіх членів кластеру. До бази даних мають бути включені питання щодо всебічної характеристики об'єкта розроблення, підприємств ОПК та промисловості й інші питання, що матимуть користь у процесі реалізації робіт, що $є$ у розпорядженні кожного члена кластеру або що будуть створені у процесі роботи над проектом; 


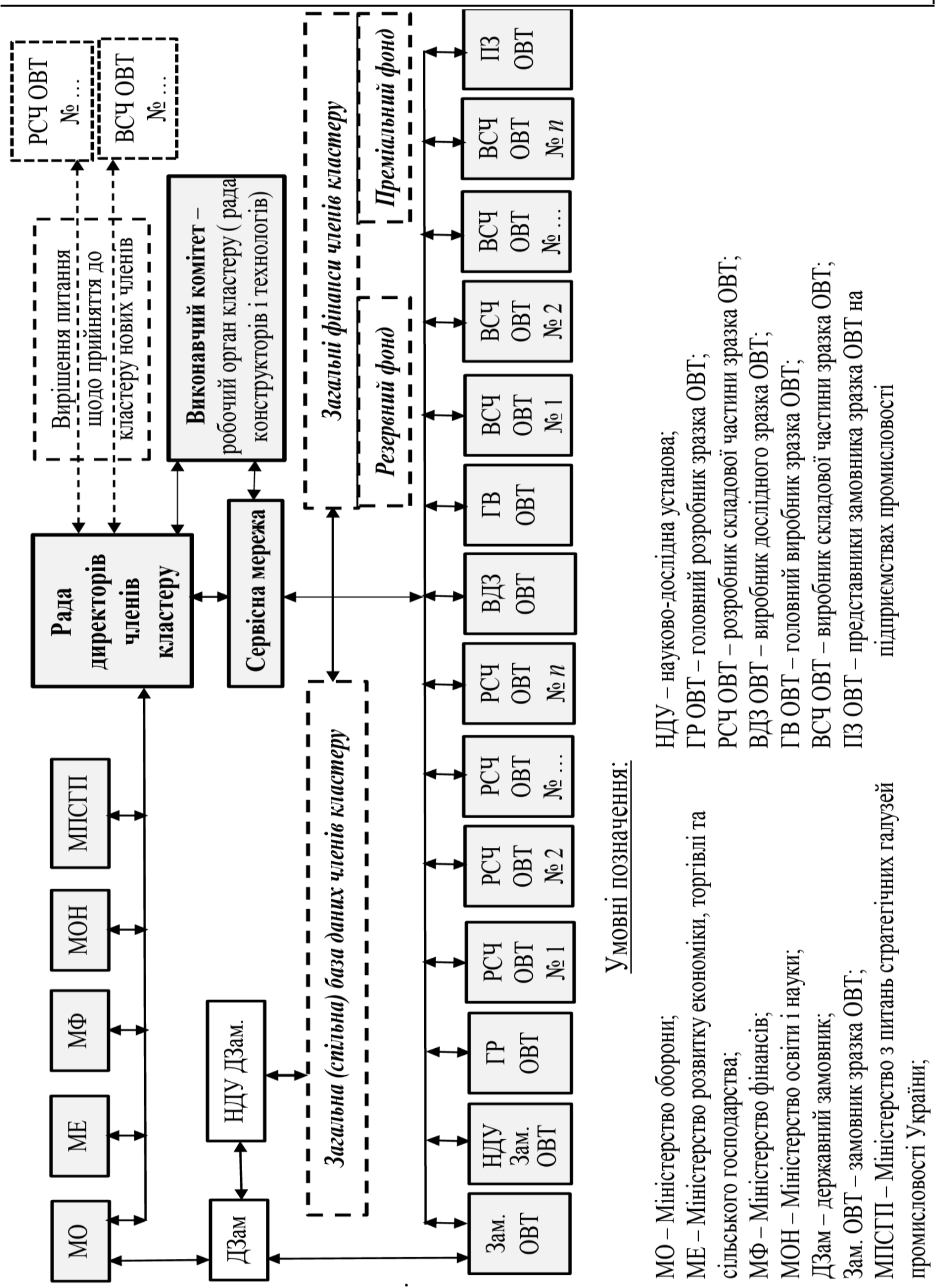

Малюнок 3 - Орієнтовна структура кластеру зі створення та серійного виробництва новітнього зразка ОВТ 
- загальні фрінанси кластеру, що мають складатися із обов'язкових внесків членів кластеру (наприклад, з початку робіт -у відсотках від отриманого на виконання замовлення бюджету, потім - з прибутку, що отримується за виготовлену продукцію внаслідок економії за результатами діяльності кластеру), так і з внесків окремих організацій і преференцій, отриманих з державного бюджету України. Дані кошти мають розподілятися на резервний фонд, що використовуватиметься на додаткове фінансування робіт окремих членів кластеру (у випадку їх гострої потреби й наявності загрози щодо можливого збільшення строків виконання робіт з розроблення окремої складової частини зразка ОВТ), та преміальний фонд, що спрямовуватиметься на стимулювання членів кластеру за результатами їхньої діяльності та подальший розвиток їхніх установ, організацій, підприємств тощо.
6. Під час виконання ДКР виконавчий комітет - робочий орган кластеру - регулярно збирається для аналізу поточної діяльності кластеру, а також у разі потреби - для вирішення складних наукових, конструктивних, технологічних, виробничих, фінансових та інших питань, що виникають у того або іншого члена кластеру, і приймає рішення щодо надання йому потрібної допомоги. Дане рішення має доповідатися Раді директорів членів кластеру, яка у найкоротшій термін має затверджувати його, уникаючи при цьому різного роду бюрократичних перепон.

7. Створений кластер супроводжує серійне виробництво розробленого новітнього зразка ОВT, надаючи наукову, конструкторську та технологічну підтримку відповідним підприємствам промисловості, що увійшли до складу кластеру, й сплачують при цьому відповідні внески до загальних фінансів кластеру.

\section{Висновки}

Таким чином, реалізація пропозицій авторів статті щодо створення кластерів з розроблення та супроводження серійного виробництва новітніх зразків ОВТ, на нашу думку, дозволить підвищити воєнну (своєчасне постачання нового зразка ОВТ до складу ЗС України), технічну (надання взаємної допомоги під час виконання робіт), економічну (заощадження державних коштів за рахунок більш ефективного їх використання) та фінансову (зацікавленість усіх учасників кластеру у найскорішому виконанні робіт та отриманні відповідного прибутку) ефективність воєнно-економічної та воєннотехнічної політики держави.

Виходячи з вищезазначеного, вважаємо, що реалізації запропонованих авторами статті пропозицій в Україні сприятиме створення у липні 2020 року у структурі центральних органів виконавчої влади Міністерства з питань стратегічних галузей промисловості України на чолі 3 віце-прем'єр-міністром України, що має відповідати, серед іншого, за формування та реалізацію ВТП України, у тому числі - за створення, організацію роботи й нормативнозаконодавче забезпечення діяльності кластерів в оборонній промисловості. На нашу думку, даний орган повинен:

- розробити Типове положення про кластери в оборонній промисловості, погодити його 3 керівниками оборонних та інших підприємств і установ;

- ініціювати внесення відповідних змін до положень щодо органів виконавчої влади та організацій - замовників;

- нормативно вирішити у законодавстві України питання щодо створення та використання фінансового фонду виконання проектів в рамках кластерів, інші пов'язані з цим питання.

Теоретичні дослідження у цій сфері треба продовжувати та посилювати, залучаючи до цього всі зацікавлені установи, організації i підприємства України різних форм власності.

\section{Список використаних джерел}

1. Закон України Про національну безпеку України // 2018. - № 2469-VIII. [Електронний pecypc]. - URL: https://zakon.rada.gov.ua/laws/ show/2469-19/. 
2. Закон України Про державне оборонне замовлення // 1999. - № 464-XIV. [Електронний pecypc]. URL: http://zakon.rada.gov.ua/go/46414.

3. Закон України Про особливості здійснення закупівель товарів, робіт і послуг для гарантованого забезпечення потреб оборони // 2016. - № 1356-VIII. [Електронний pecypc]. - URL: http://zakon.rada.gov.ua/go /1356-19.

4. Постанова КМ України Питання державного оборонного замовлення // 2011. № 464. [Електронний ресурс]. - URL: http://zakon.rada.gov.ua/go/464-2011-п.

5. Постанова КМ України Про затвердження Порядку розроблення, освоєння та випуску нових видів продукції оборонного призначення, а також припинення випуску існуючих видів такої продукції // 2013. - № 120. [Електронний ресурс]. - URL: https://zakon.rada.gov.ua/laws/show/120-2013$\% \mathrm{DO} \% \mathrm{BF}$.

6. Постанова КМ України Про затвердження Порядку формування ціни на продукцію, роботи, послуги оборонного призначення у разі, коли відбір виконавців з постачання (закупівлі) такої продукції, робіт, послуг здійснюється без застосування конкурентних процедур // 2016. - №517. [Електронний pecypc]. - URL: http://zakon.rada.gov.ua/go/5172016-п.

7. Портер Майкл Э. Конкуренция: Пер. с англ. - М.: Издательский дом "Вильямс", 2005. C. 256.

8. Доброва К.Б. Кластер как инструмент повышения конкурентоспособности и инновационной активности предприятий оборонно-промышленного комплекса. МИР (Модернизация. Инновации. Развитие). 2017. T. 8. № 3. С. 396-403.

9. European Defence Agency Regional Industrial Portals \& Clusters. [Електронний pecypc]. - URL: https://www.eda.europa.eu/ industry-info/directories/industry-rto-directory/ regional-industrial-portals-clusters.

10. European Network of Defence-Related Regions: Croatian Defense Industry Competitiveness Cluster. [Електронний ресурc]. URL: https://www.endr.eu/organisation/ croatian-defense-industry-competitivenesscluster.

11. Kadir Alpaslan Demir, Fahri Erenel, Ebru Caymaz Defense Industry Clusters in Turkey. [Електронний ресурс]. - URL: https://www.researchgate.net/publication/3044 25124_Defense_Industry_Clusters_in_Turkey.

12. Paul Hackett Strength in numbers: the benefits when firms join forces. [Електронний pecypc]. - URL: https://www.euronews.com/ 2020/02/21/strength-in-numbers-the-benefitswhen-firms-join-forces.

13. Kadir Alpaslan Demir, Fahri Erenel, Ebru Caymaz Defense Industry Clusters in Turkey. [Електронний ресурc]. - URL: https://www. researchgate.net/publication/304425124_Defens e_Industry_Clusters_in_Turkey.

14. Кластерізація "Укроборонпрому": детально про реформу обороннопромислового комплексу України. [Електронний ресурс]. - URL: https://ukroboronprom.com.ua/uk/media/klaste ryzatsiya-ukroboronpromu-detalno-pro-reformuoboronno-promyslovogo-kompleksu-ukrayinyartur-heruvimov.html.

15. "Укроборонпром" презентував стратегію оборонно-промислового комплексу України. [Електронний ресурс]. - URL: https://ukroboronprom.com.ua/uk/media/ukrob oronprom-prezentuvav-strategiyu-reformyoboronno-promyslovogo-kompleksuukrayiny.html.

16. Розпорядження КМ України Про схвалення Стратегії розвитку обороннопромислового комплексу України на період до 2028 року // 2018. - № 442-р. [Електронний pecypc]. - URL: https://zakon.rada.gov.ua/ laws/show/442-2018-\%D1\%80\#n7. 


\title{
Возможность применения кластерного подхода при разработке и производстве вооружения и военной техники в Украине
}

\author{
Валерий Борохвостов * А; Владимир Комаров ${ }^{\text {; }}$ Леся Скуриневськая с; \\ Анастасия Шевченко ${ }^{D}$ \\ *Corresponding author: ведущий научный сотрудник, к.т.н., доцент, e-mail: bvk51@ukr.net, ORCID: 0000-0001-6341-9042 \\ АЦентральный научно-исследовательский институт вооружения и военной техники Вооруженных Сил Украины, \\ пр-кт Воздухофлотский, 28, г. Киев, 03049, Украина \\ в Воинская часть А1906, г. Киев-04050, Украина \\ ' Национальный университет оборони Украины имени Ивана Черняховского, пр-кт Воздухофлотский, 28, г. Киев, 03049, Украина \\ D Национальный институт стратегических исследований, улица Пирогова, 7а, г. Киев, 01030, Украина
}

\begin{abstract}
Аннотация
Существенные изменения в геостратегическом, военно-политическом, социальноэкономическом и демографическом состоянии Украине, которые произошли за годы независимости, особенно ускорились в последние годы. Именно они вызывают необходимость разработки новых подходов к вопросам обеспечения ее национальной безопасности в военной сфере, в том числе - по определению наиболее рациональных с военной и экономической точек зрения путей обеспечения Вооруженных Сил Украины новейшими и модернизированными образцами вооружения и военной техники в сжатые сроки, а также решения многих других вопросов военно-технической политики Украины. Существующая в Украине система оборонного планирования и развития вооружения и военной техники, в основном, позволяет комплексно обосновывать выделение финансовых ресурсов на разработку и закупку вооружения и военной техники для нужд сил обороны. В то же время, имеется ряд проблемных вопросов, которые не позволяют повысить военно-экономическую эффективность проводимых работ.

Исходя из этого, в статье, на основе анализа производственно-экономических процессов и форм организации производства в оборонной промышленности отдельных стран мира, раскрыты сущность, преимущества и возможные пути реализации кластерного подхода, который может быть применен при разработке и серийном производстве новых образцов вооружения и военной техники в Украине.

На примерах показано, что многими странами мира уже накоплен значительный успешный опыт развития кластеров в оборонной индустрии, что позволяет получить наиболее эффективную модель сотрудничества между государством, бизнесом, наукой и конечными потребителями с учетом специфики сектора безопасности и обороны.

Исходя из этого, предложена общая структура такого кластера, детализирован порядок его создания и принципы функционирования, а также возможное влияние на повышение эффективности реализации программ технического оснащения Вооруженных Сил Украины.
\end{abstract}

Ключевые слова: военно-техническая политика, вооружение и военная техника, государственный оборонный заказ, кластер, разработка вооружения и военной техники, серийное производство вооружения и военной техники, управляющая кластерная организация

\section{Clustering of the defense industry as a factor of increasing the efficiency of military-technical policy of Ukraine}

\author{
Valerii Borokhvostov * A; Volodymyr Komarov ${ }^{B}$; Lesia Skurinevska C; \\ Anastacia Shevchenko ${ }^{D}$
}

*Corresponding author: Candidate of Technical Sciences (Ph.D.), Associate Professor, Leading Researcher, e-mail: bvk51@ukr.net, ORCID: 0000-0001-6341-9042 
${ }^{A}$ Central Research Institute of Armaments and Military Equipment of the Armed Forces of Ukraine, 28, Povitroflotskyi Ave, Kyiv, 03049, Ukraine ${ }^{B}$ Military Unit A1906, Kyiv, 01001, Ukraine

c The National Defence University of Ukraine named after Ivan Cherniakhovskyi, 28, Povitroflotskyi Ave., Kyiv, 03049, Ukraine

D National Institute for Strategic Studies, 7A, Pyrohova Str., Kyiv, 01054, Ukraine

\begin{abstract}
Major developments in the geostrategic, military-political, socio-economical and demographical state during the independence of Ukraine have particularly accelerated in the last years. Due to these developments, a necessity of developing new approaches towards providing national security in the military domain has arisen, including those dedicated to determining the most rational paths (from both military and economic point of views) of rapidly supplying the Armed Forces of Ukraine with newest and modernized models of weaponry and military equipment, as well as solving a variety of other issues of the Ukrainian military and technological policy.

The existing system of defense planning, weaponry and military equipment development in Ukraine, in general, allows a complex substantiation of financial resources allocation towards weaponry and military equipment development and procurement for defense purposes. However, a number of problematic issues exist, that impede both military and economic effectiveness of ongoing work.

In this article, an analysis of production and economic processes, as well as forms of organizing production in the defense industry of several countries is carried out, revealing the nature of the cluster approach, its advantages and possible implementation directions. This cluster approach can be applied to develop and mass produce new models of weaponry and military equipment in Ukraine.

It is illustrated that many world countries already possess substantial experience in developing defense industry clusters, which allows to achieve the most effective model of collaboration between the state, business, scientific establishment and the end user with an emphasis on defense and security sector specifics.

A general structure of such a cluster is proposed, a detailed method of creation, functioning principles, as well as its possible influence on increasing the effectiveness of military equipment programs carried out in the interests of the Armed Forces of Ukraine.
\end{abstract}

Keywords: military and technological policy, weaponry and military equipment, national defense procurement, cluster, weaponry and military equipment development, mass production of weaponry and military equipment, cluster managing organization.

\title{
References
}

1. Law of Ukraine on the national security of Ukraine № 2469-VIII (2018, June 21) Vidomosti Verkhovnoyi Rady Ukrayiny, 31, 241 [in Ukrainian].

2. Law of Ukraine on the state defense order No464-XIV (1999, March 3) Vidomosti Verkhovnoyi Rady Ukrayiny, 17, 111 [in Ukrainian].

3. Law of Ukraine on the peculiarities of procurement of goods, works and services for the guaranteed provision of defense needs № 1356-VIII (2016, May 12) Vidomosti Verkhovnoyi Rady Ukrayiny, 24, 488 [in Ukrainian].

4. Resolution of the Cabinet of Ministers of Ukraine Issues of the state defense order No 464 (2011, April 27) Retrieved from: http://zakon.rada.gov.ua/go/464-2011-п. [in Ukrainian].

5. Resolution of the Cabinet of Ministers of Ukraine on the approval of the Order of development, acquisition and release of new types of defense products, and termination of release of existing types of such products № 120 (2013, February 20) Retrieved from: https://zakon.rada.gov.ua/laws/show/1202013-\%D0\%BF [in Ukrainian].

6. Resolution of the Cabinet of Ministers of Ukraine on the approval of the procedure of forming the price of products, works, services for defense purposes $n$ the case when the selection of contractors for the supply (purchase) of such products, works, services is carried out without the use of competitive 
procedures № 517 (2016, August 8) from:

Retrieved from: https://www.euronews.com/2020/02/21/str http://zakon.rada.gov.ua/go/517-2016-ח [in ength-in-numbers-the-benefits-when-firmsUkrainian].

7. Porter, M. (2005) On Competition Moscow: "Williams" Publishing house p. 256 [in Russian]

8. Dobrova, K.B. Cluster as a Tool to Increase the Competitiveness and Innovative Activity of Enterprises of the Defense Industry Complex. MIR (Modernization. Innovation. Research). 2017;8(3):396-403. (In Russ.) DOI: 10.18184/2079-4665.2017.8.3.396-403 [in Russian]

9. European Defence Agency Regional Industrial Portals \& Clusters. Retrieved from: https://www.eda.europa.eu/industry-info/ directories/industry-rto-directory/regionalindustrial-portals-clusters [in English].

10. European Network of Defence-Related Regions: Croatian Defense Industry Competitiveness Cluster. Retrieved from: https://www.endr.eu/organisation/croatiandefense-industry-competitiveness-cluster. [in English].

11. Kadir Alpaslan Demir, Fahri Erenel, Ebru Caymaz Defense Industry Clusters in Turkey. Retrieved from: https://www.researchgate. net/publication/304425124_Defense_Indust ry_Clusters_in_Turkey. [in English].

12. Paul Hackett Strength in numbers: the benefits when firms join forces. Retrieved join-forces. [in English].

13. Kadir Alpaslan Demir, Fahri Erenel, Ebru Caymaz Defense Industry Clusters in Turkey. Retrieved from: https://www.researchgate. net/publication/304425124_Defense_Indust ry_Clusters_in_Turkey. [in English].

14. Clusterization of "Ukroboronprom": on the reform of the defense-industrial complex of Ukraine in detail. Retrieved from: https://ukroboronprom.com.ua/uk/media/k lasteryzatsiya-ukroboronpromu-detalnopro-reformu-oboronno-promyslovogokompleksu-ukrayiny-artur-heruvimov.html. [in Ukrainian].

15. "Ukroboronprom" presented the strategy of the defense-industrial complex of Ukraine Retrieved from: https://ukroboronprom.com.ua/uk/media/u kroboronprom-prezentuvav-strategiyureformy-oboronno-promyslovogokompleksu-ukrayiny.html. [in Ukrainian].

16. Order of the Cabinet of Ministers of Ukraine on the approval of the Strategy for the development of the defense-industrial complex of Ukraine up to 2028 № 442-p (2018, June 20) Retrieved from: https://zakon.rada.gov.ua/ laws/show/4422018-\%D1\%80\#n7 [in Ukrainian]. 